gastrula ectoderm into mesoderm, after contact for $3 \mathrm{hr}$. with a protein fraction from guinea-pig bone marrow. He was studying the mechanism of this conversion, and also of the regeneration of lens from iris cells, by autoradiography, fluorescent antibody techniques and electron microscopy. Dr. Grobstein pleaded for a distinction between 'heterotypic' and 'homotypic' control of cell differentiation, to interpret the dependence of pancreatic epithelium not only on the presence of mesenchyme but also on integrity of reasonably large epithelial pieces, for good differentiation of acini. Dr. Moscona, describing the ability of mixed cultures of dissociated mouse and chick tissues to form composite organs whereas cells of different tissue types from the same animal do not combine, pointed out that after an initial nonselective phase of reaggregation the cells sort out into distinct tissue types by a process which he believes may depend on a molecular fit between protein and carbohydrato at the cell surfaces. The problem he raised of how embryonic cells recognize each other needs linking up with theories about the development of immune mechanisms in embryos, but in an evening round-table discussion on this topic the cellular embryologists failed to get to grips with the immunologists. Immunologists who spoke at the conference were Dr. T. Makinodan (Oak Ridge), who emphasized the importance of plasmacell differentiation during immuno response, and Dr. G. Möller (Karolinska Institutet), who described brilliantly the use of tumour-cell strains to study tissue antigenicity and pointed out discrepancios that had arisen in dating the earliest appearance of transplantation antigens in developing animals by different methods. Dr. R. E. Billingham (The Wistar Institute, Philadelphia) brought together genetical and immunological considerations in reviewing the different abilities of bone marrow and lymph-node tissues to induce tolerance of skin grafts, when different strain crosses of rats and mice were used.

Anothor aspect of cell differentiation was dealt with by Prof. C. H. Waddington (University of Edinburgh), who showed electron micrographs of developing amphibian notochord cells, and of ommatidia of normal and eye-mutant strains of Drosophila. He also showed a film illustrating the different behaviour of myoblast and neural cells in culture, even before they are structurally distinguishable. Any theory of differentiation controlled by genes has to account for the regional differentiation within cells that is now visible in electron micrographs, as well as how such differences are established when the cell-contents are in constant commotion as the ciné pictures show.

In his final summary of the conference, Sir Macfarlane Burnet (The Walter and Eliza Hall Institute of Medical Research, Melbourne) reiterated that genetic information must control all types of differentiation, and he called for an intensified study of gene-controlled immunological anomalies, such as human a-gammaglobulinarnia. Ho also pointed out our complete ignorance of whether systemic immune mechanisms exist in invertebrates, which do not appear to possess gamma-globulins.

Other speakers at the conference were Drs. L. Herzenberg (Stanford University) and A. J. Riker (University of Wisconsin), who described differentiation in cultures of mouse lymphoma, and gall-infected plant tissues, respectively, and Dr. V. Hamburger (Washington University, St. Louis), who reviewed evidence for cell-specificity in the development of the nervous system. The full proceedings, including discussions, will be published as a supplement to the Journal of Cellular and Comparative Physiology later this year.

E. M. Detchar

\title{
GRAZING IN TERRESTRIAL, FRESHWATER AND MARINE ENVIRONMENTS
}

T HE fourth symposium to be arranged by the British Ecological Society was held at the University College of North Wales, Bangor, during April 11-14. The subject was treated in the broadest sense, and included not only pasture and range grazing by terrestrial herbivores but also planktonic grazing and other grazing-like phenomena of freshwater and marine environments.

In the first contribution to the symposium, Mr. A. Macfadyen, Zoology Department, University of Swansea, classified the main routes through which matter and energy can flow in a model ecosystem, and discussed the magnitudes of the main trophic components in several contrasting systems, including grassland and plankton. The relationship between stock and productivity can vary ovor several orders of magnitude, according to the biology of the organisms concerned. Thus the standing crop of plant material in the marine environment is very small compared with that in terrestrial environments, although the nergy-flow is of similar magnitude. Grazing yields can be reduced by energy-flow into unproductive pathways, such as ungrazed organic matter by plants, and inefficient utilization of plant material by herbivores. It is therefore clearly important to have a framework within which to compare present performances of ccosystems with potential yields.

Mr. M. B. Alcock, Department of Agriculture, University College of North Wales, Bangor, discussed the problem of achieving maximum output of animal products from grassland. The responses of the plant to defoliation may be due to changes in root growth and uptake of minerals, to utilization of carbohydrate reserves, or to changes in the interception of light energy.

Dr. J. D. Ovington, Nature Conservancy, St. Tves, Huntingdonshire, described work carried out at the University of Minnesota in which he compared the productivity of prairie, savanna and oakwood. The presence of woody plants greatly increases the nutrient circulation and utilization of the site, with the result that the primary productivity of the oakwood almost reaches that of intensively managed fields of maize nearby.

Prof. L. B. Slobodkin, University of Michigan, discussed grazing phenomona in fresh-water, and emphasized that the limited extent and uniformity of most freshwater environments leads to unstable rolationships between planktonic species and, in consequence, to wide fluctuations in population numbers. 
Dr. Cushing, of the Fisheries Laboratory, Lowestoft, summarized existing knowledge bearing on one of the economically important food chains in the North Sea. He compared the efficient utilization of the planktonic herbivore Calanus by the herring with the apparently wasteful feeding on diatoms by Calanus itself. In certain years at least, zooplankton grazing limits the growth of phytoplankton. More detailed information on the nutrition and reproduction of Calanus obtained from laboratory work was given in a later contribution by Dr. Marshall and Dr. Orr, of the Marine Station, Millport. Dr. D. T. Gauld, Zoology Department, University of Aberdeen, described a second mode of feeding by means of which certain copepods, including possibly Calanus, can augment their diet. The maxillæ can be used by the larger copepods not only as passive filtering organs but also as an active 'sweep net' to catch the larger diatoms, dinoflagellates and even animal food.

A further session was devoted to examples of the activities of organisms which occupy a significant place as 'grazers' in various marine habitats. For. tunately, the discussion provoked by the fascinating problems which the speakers introduced took precedence over any consideration of what phenomena should properly be regarded as 'grazing'. Dr. D. J. Crisp, Marine Biology Station, University College of North Wales, considered how the food requirements of barnacles, as measured from growth-rates and feeding-rates, can be met from the amount of suspended matter in sea-water, and concluded that growth is usually limited by the availability of food. Mr. P. R. Walne, of the Fisheries Laboratory, Conway, emphasized the importance of the quality and concentration of phytoplankton cells constituting the food of marine bivalve larvæ. In the laboratory, good growth necessitates a higher concentration of cells than normally occurs in the sea, and it is possible therefore that some other source is available to naturally occurring larvæ. Grazing by limpets was reviewed in the contribution from Dr. A. J. Southward, of the Laboratory, Plymouth. The grazing-rate of the common limpet was measured by observations on algae-covered aquarium surfaces; however, under natural conditions, limpets remove not merely algae but also considerable quantities of the softer rocks such as chalk and limestone. Dr. T. E. Thompson, Department of Zoology, University College, Cardiff, directed attention to the very specialized diet of many nudibranchs; it is possible that the veliger larvæ of some nudibranchs can recognize the presence of their prey and respond by settling on it. Nudibranchs which pass through several generations in a season are prodigal feeders of transitory prey, whereas those with annual life-cycles browse more sparingly on stable and abundant populations of food organisms. Mr. P. J. S. Boaden, Department of Zoology, Queen's University, Belfast, dealt with food relationships within sand and gravel. The interstitial fauna consumes dead organic matter, bacteria, and autotrophs such as diatoms, sometimes removing them individually from grains of sand. The number of animals found in the interstitial spaces indicates that coarse sands contain a fairly rich source of food for the large indiscriminate sand grazers.

Several papers were devoted to the influence of grazing animals, both indigenous and introduced, on terrestrial vegetation. Dr. D. F. Costello, of the U.S. Department of Agriculture, Portland, Oregon, described how ecological research has led to improved practices in range management, especially with regard to re-vegetation, eradication of harmful species, prevention of land erosion and controlled grazing. Dr. J. W. Marr, of the Institute of Arctic and Alpine Research, University of Colorado, and Dr. D. R. Flook, of the Canadian Wildlife Service, Edmonton, Alberta, described the soil conditions, the natural vegetation and the dominant herbivores of the Alpine tundra of the Front Range, Colorado, and of the Banff and Jasper Natural Parks, Alberta. Mrs. D. J. Carr, Department of Botany, Queen's University, Belfast, described degenerative changes and the early stages of accelerated erosion in certain areas of the Bogong High Plains, Victoria, which are believed to be a consequence of their use for summer grazing by the European settlers. Changes extending over a much longer time-scale were described by Dr. R. L. Dix for the North American grassland. The original grassland was traced from its formation in the central Great Plains area during the late Oligocene or Miocene to the present century.

Prof. F. A. Pitelka, and Dr. A. M. Schultz, of the University of California, Berkeley, introduced evidence obtained at the Arctic Research Laboratory, Barrow, Alaska, on the well-known cyclic fluctuations in the populations of the brown lemming, Lemnus trimucronatus. These regular changes can be explained on the basis of a simple interaction between herbivore and vegetation with a three-year nutrient cycle. Following overgrazing in a peak year, the nutrients are only slowly recovered and made available again by the third year, and by this time the plant cover has reached a sufficient quantity and quality to support another rapid population increase. Cycles in plant production and in soil nutrient-level were found to correlate with population changes in the lemmings.

The last session of the symposium dealt with the effects of animal behaviour on grazing. Dr. G. W. Arnold, of the Commonwealth Scientific and Industrial Research Organization, Division of Plant Industry, Canberra, discussed the importance of the animal's behaviour in selecting and harvesting its food to its nutrition and to the productivity of the system. Decreasing the availability of suitable pasture, though at first compensated by an increase in the time of grazing, eventually leads to a reduction in the total intake of food. Dr. R. Elfyn Hughes, of the Nature Conservancy, Bangor, described experiments on productivity in which the sheep were allowed to distribute themselves voluntarily between richer and poorer mountain pasture.

A technique for analysing sheep diet from epidermal plant fragments identified from fæces, which has a distinct advantage over fistula sampling methods, was described by Dr. D. J. Martin, West of Scotland Agricultural College. A surprising observation, which was confirmed by others taking part in the discussion, was reported by Dr. R. F. Hunter, of the Hill Farming Research Organization. Sheep do not appear to roam freely, but form family groups which restrict themselves to certain territories differing in altitude, aspect and vegetation. This finding is of obvious importance to management of hill sheep. It may also vitiate attempts at breeding by simple selection if the desirable characteristics are attributable more to the home range environment of the sub-flock than to genetic differences.

The proceedings of the symposium will be published and will represent the fourth of the series published by the Society.
D. J. CRISP 